\title{
Influence of RQA Learning Model toward Student Concepts Understanding and Retention at SMA 2 Kasimbar
}

\author{
Lilies Tangge \\ Universitas Tadulako \\ Palu, Indonesia \\ liliestangge@yahoo.com
}

Amran Rede

Universitas Tadulako

Palu, Indonesia

\author{
Nurafriani \\ Universitas Tadulako \\ Palu, Indonesia
}

\begin{abstract}
This study has been conducted in SMA Negeri 2 Kasimbar On October and November 2016 which aims to determine the influence of RQA learning model toward the insight of concepts and retention of grade X SMAN 2 Kasimbar. Design of this study is nonequivalent control group design. The subject of the study consisted of two classes, namely class $X \mathrm{~A}$ as a control and class $X \quad B$ as an experiment, by sum 60 students. Data collection techniques used is a test. Validity and reliability tests were performed using ANATES. The data analysis technique used to test the hypothesis is t-test. The results study showed that: (1) concept understanding between the experimental class and control class gained significance level (p) $0,041<\alpha=0,05$ or $\mathrm{H}_{0}$ is rejected, which means a significant influence on the use of the learning model RQA students concepts understanding, (2) retention between the experimental class and control class gained significance level (p) $0,041<\alpha=0,05$ or $\mathrm{H}_{0}$ is rejected, which means a significant influence on the use of the learning model student retention.
\end{abstract}

Keywords: RQA; Concepts Understanding; Retention.

\section{INTRODUCTION}

Learning is a process of interaction of learners with educators and learning resources in a learning environment. Learning is a deliberate effort, focus and aims to allow others to gain meaningful experience [1]. Learning science from elementary schools to universities should be able to develop students' thinking skills to a more mature, work together, be open, self-confidence, work skills, communication skills and other social skills [2]. Therefore, it is very important for any teacher to understand as well as possible about the student's learning process, in order to provide guidance and providing the proper learning environment for students and harmonious.
How to convey science in the learning process is a major aspect of the educational process. The experience of learning experienced by students during the learning takes place will be very instrumental in the formation of a wide range of student abilities and be a reflection of the quality of the learning. The quality of learning is one element of the new paradigm of management education in high school [3]. Therefore, teachers have a great responsibility in shaping the student's learning experience. One way that can be used is to use a learning model that is capable of organizing the learning experience of students to achieve the learning objectives. The use of models in the learning process is an effort to improve the quality of the learning process that can ultimately improve the quality of student learning outcomes.

The learning model is a pattern of action or line of thinking that is designed such and contain a sequential set of procedures to create a process. A learning model covers the entire learning system that includes components of interest, conditions of learning, teaching and learning process and evaluation of learning outcomes. The learning model is used to attract the attention of students in learning and teaching materials will be more easily understood by the students. The learning objectives can be achieved if the learning is done by effective implementation.

Learning will take place properly if teachers are able to apply the appropriate learning models. Therefore, the learning model used should be attractive and innovative in order to attract students to learn and to improve student achievement, and reduce the difficulty of students to understand the material being taught.

Constructivism learning model is learning patterns that condition the students to actively construct a new concept, a new understanding, a new knowledge based on data from the information and prior knowledge. According to this 
understanding, learning not only imitate what is taught or read out but to create understanding [4]. Learning constructivism position of equality between teachers and students in the learning process enabling the process of elaboration of the principles and concepts learned in order to build a meaningful new knowledge. Effective learning in view of Constructivism not only help the acquisition and mastery of knowledge, speed, and accuracy of work but must also be efficient, interesting and fun.

One model of learning that is included in the constructivist approach is a learning model RQA (Reading Questioning and Answering). This model has the syntax: a) Reading, where students are assigned to read the lesson material; b) Questioning, students formulate written questions about things that are not yet understood from reading material; c) Answering, students answer the questions in writing. At the time of learning, the student is asked to present questions and answers. Students are also asked to provide feedback, input, feedback, or ask other questions related to the presentation. RQA learning model is expected of students more active, more critical in solving problems and more responsible for the tasks assigned, but that with this model of learners expected to be more zealous in teaching and learning. Based on the learning patterns like this provide an opportunity to increase understanding of concepts and retention of students.

Preliminary observations made before the study was conducted in the form of direct interviews between investigators with some teachers and some students at SMAN 2 Kasimbar. Results of interviews with students obtained information that the learning method in SMA 2 Kasimbar generally still conventional (teacher-centered learning). Although learning with conventional strategies have been pursued by teachers using ICT-based learning media (information and communication technology), but the results are still not good as it has been shown in the results of students' cognitive learning. Low cognitive achievement recognized by the students that they do not understand the material that has been taught. This is because students just tend to be silent during the learning process, no interaction, and communication, or feedback between teachers and students and between students and students during the learning process. In addition, students also said that they rarely learn or rarely read. This statement is corroborated by research conducted by [5], the students Prodi Biology IAIN Ar-Raniry that follow the course of Anatomy Plant, found that reading interest of students to the lecture material to prepare coursework next is still very low, so the initial knowledge of students when lectures take place is still lacking. This results in lower activity and student learning outcomes.

On the other hand, a study conducted by [3] about the Effects of Application of Learning Model of Reading, Questioning and Answering (RQA) to Knowledge Metacognitive Grade XI IPA at SMAN 2 in Ternate, the results of this study indicate a difference in student learning outcomes in metacognitive skills and mastery of concepts by using model RQA and conventional learning on the concept of the reproductive system. RQA model application can enhance metacognitive skills and mastery of concepts students on the concept of the reproductive system.
Based on the facts in the field, theory and results of previous studies that researchers interested in conducting research on the Effects of Learning Model RQA (Reading, Questioning, and Answering) On the Concept Training and Retention Class X SMAN 2 Kasimbar on Subjects Biology.

\section{METHODS}

This type of research is quasi-experimental (QuasiExperimental) using research design nonequivalent control group design, in which a group of subjects drawn from a particular population and conducted a pretest and then subjected to treatment. Once subjected to treatment, subjects were given a posttest to measure the effect of treatment in this group. The instruments are supplied containing the same weight. The difference between the results of the pretest to posttest shows the results of the treatment that has been given [6].

The research was conducted at SMAN 2 Kasimbar at Jl. Trans Sulawesi Silampayang village in October and November 2016. The population of this research was all students at SMAN 2 Kasimbar. This school is a new school is active in the academic year 2016/2017, so that the available class is a class $\mathrm{X}$, a class X A and X B, each class numbered 30 students so that the overall number of students in the academic year $2016 / 2017$ is 60 students. Samples were taken from the whole of the population is taken as a data source [7]. Therefore, the sample was class X A totaling 30 students and X B totaling 30 students. To determine the experimental and control classes conducted randomly in order to obtain class $\mathrm{X}$ as the control class A and class X B as an experimental class.

The research instrument used in the form of a test used to see the students' understanding of concepts and retention of students. Before being used in the study to test the instrument by validating construction (validation expert) and validation trials for pretest and posttest, and then measuring the level of validity and reliability, and to retest validation construction so that it can be considered whether the instrument can be used or not, test instruments analyzed using ANATES.

Data collection techniques used in this study of the test (pretest, posttest, and retest) who have valid and reliable. Data analysis techniques with inferential statistics are used for connection with the research hypothesis testing. Parametric statistical hypothesis testing used by using t-test. According to [8] before carrying out this analysis (hypothesis testing), it is first tested prerequisites, which include:

Test for normality by using the One-Sample Kolmogorov Smirnov Test using SPSS version 16.0 and learning outcomes data from the samples will be distributed normally if sig. > ? with $\mathrm{a}=0.05$ level.

Variant homogeneity test using Levene's Test of Error Variance using SPSS version 16.0. Testing criteria used are a sig. > ? with a level of $\mathrm{a}=0: 05$.

After going through the prerequisite test, the analysis continued to test the hypothesis, using statistical analysis independent t-test and test criteria is $\mathrm{H} 0$ is rejected if sig. $<$ ? = 0.05 which means there is a difference between the two men, in this case between the data groups of experimental data and the 
control group, which means that there is the influence of conceptual understanding and retention between groups learning model RQA and the group not using the model so that it can be said that learning using RQA learning model can improve student understanding and retention concepts. H0 if sig. $>$ ? $=0: 05$ means no meaningful difference between the data experimental group and the control group, which means that there is no influence of conceptual understanding and retention of students between groups learning model RQA and the group not using the model. Testing the hypothesis in this study using the program Statistical Package for Social Science (SPSS) version 16 o'clock.

\section{RESULTS AND DISCUSSION}

Research results in the form of scores obtained from measuring devices in the form of tests on the effect of RQA to the understanding of the concept of students and retention of class X SMA Negeri 2 Kasimbar treated with the following steps: (1) the test result data research instruments; (2) precondition test data analysis; (3) The results of hypothesis testing.

Test instruments testing done in two stages, namely the validity and reliability. This test is used to declare the validity and reliability of the items of instruments used in the study. Experiments performed in this study was conducted on 25 students of class X D SMA Negeri 1 Kasimbar.

Based on the test results with the number of tests of 20 essays gained 10 essays that are used as a standard test. Whereas, for the matter of the retention of the number of tests that are validated by 55 experts about stuffing and stuffing acquired 55 used as a standard test, then used as a final test to determine the understanding of concepts and retention of students who take the learning process by the learning model and conventional RQA. This test analyzed using ANATES application.

Based on test results obtained sig normality. $>0.05$ in all the experimental and control class data, the research data obtained from the population that is normally distributed.

Based on test results obtained sig homogeneity. $>0.05$ in all the experimental and control class data, the research data obtained from the population that has the same variance or homogeneous.

Results of the test of precondition analysis showed that the scores of each variable studies have been eligible for a further statistical test that hypothesis testing. Hypothesis testing is performed divided into two hypotheses about the concept and understanding of student retention.

Hypothesis testing students' understanding of the concept using t-test analysis shows that sig $<$ ? then $\mathrm{H}_{0}$ is rejected. From the results obtained the significant value $(0.041)$ is smaller than the value $=0.05$, then $\mathrm{H}_{0}$ in this study was rejected and $\mathrm{H} 1$ accepted, which means there is the effect of the use of RQA to the understanding of the concept of class X SMA Negeri 2 Kasimbar in biology.
Student retention hypothesis testing using t-test analysis shows that sig $<$ ? then $\mathrm{H}_{0}$ is rejected. Results obtained the significant value $(0.041)$ is smaller than the value $?=0.05$ then, in this study rejected $\mathrm{H}_{0}$ and $\mathrm{H}_{1}$ accepted which means no influence on the retention RQA use class X SMA Negeri 2 Kasimbar in biology.

This study aimed to examine the effect of the learning model RQA to the understanding of students' concept and to test the effect of the learning model RQA on the retention of students who take the learning process biology class X SMA Negeri 2 Kasimbar. Implementation of the study, students were given a pretest beforehand which aims to determine the initial conditions of the students' knowledge of biology virus before being given treatment. Then proceed with the learning activities with group discussion method using model RQA the experimental class and learning with lecture method without using the learning model RQA the control class. At the end of the delivery of content supplied again posttest with the same measuring instrument at the time of the pretest, posttest results will be tested further statistics to see whether there is influence RQA to the understanding of the concept of the student.

Based on the post-test data analysis understanding the concept of independent sample t-test test obtained sig. $(\mathrm{P})=$ 0,041 with the testing criteria $\mathrm{a}=5 \%(0.05)$ so that $0.041<0.05$ (H1 accepted) can thus be interpreted that "there is a learning model RQA influence on students' understanding of the concept".

Analysis of the data retention of students in independent sample t-test test obtained by value $\operatorname{sig}(\mathrm{p})=0,041$ with the testing criteria $\mathrm{a}=5 \%(0.05)$ so that $0.041<0.05$ (H1 accepted) can thus be interpreted that "there is the influence of the model RQA learning on the retention of Shiva ".

Values experimental group was higher than the control class is not a coincidence, but the difference is due to differences in the treatment of researchers in using learning model RQA during the learning process. Virus concept taught in the experimental class and control class is a similar concept, but the difference is only in the experimental class using RQA learning model, while the control class only use the lecture method without learning model. The results of this study reinforce the theory Institution (2006), which states that people who have a good memory are not born but created. Based on the results of this study were associated with the theory Institution (2006) of memory, it can be concluded that everyone has an equal opportunity to have a good memory. A good memory certainly possessed by those who diligently hone his memory by reading or studying diligently and not get tired to repeat the lessons that have been studied previously. In this study, reading, ask and answer, as well as an active learning environment, helping students to more easily understand and remember the material they have learned.

In this study, the effectiveness conceptually can be interpreted as a treatment in the learning process which has the characteristics: a) an atmosphere that can affect or things that impressed during the learning process, and b) the success of the business or actions that affect student learning outcomes. The effectiveness of learning through reading, ask and answer can be seen from the level of student activity when discussions. 
Discussion based on existing knowledge for reading can arouse emotions and attitudes. Ref. [9] suggests that the use of the learning model constructivism can motivate students to realize that learning is the responsibility of the students themselves which can be demonstrated by the ability of students to develop the knowledge to ask questions and find their own answers, helping students to develop a sense and understanding of concepts in addition, developing the ability of students to become independent thinkers and more emphasis on the process of learning how to learn it. The use of constructivist-oriented learning model will greatly assist the effectiveness of the learning process and delivery of learning content in accordance with the demands of the curriculum.

The high retention grade students experiment using the model because the students are learning RQA previously only get learning with lecture and just given the task. It makes students feel bored and tired so that students are not serious about learning so that low retention. RQA (Reading, Questioning, and Answering) is a learning model that is based on constructivist that students are active in the process of learning. Students are conditioned to perform an active process in developing the concept, understanding and new knowledge based on facts, information, and knowledge that has been previously owned. Active students in learning sparked students' interest in learning. This learning process encourages students to organize his own experience into a meaningful new knowledge. Students not only digest just what is presented by the teacher but also build new relationships of concepts and principles learned and manage the process of thinking. Conditions such as self-regulated learning can grow and develop properly so that students are able to actualize the requirements in accordance with their potential.

As previous studies research results by [3] which states their influence on the mastery learning model RQA concept of class XI IPA at SMAN 2 in Ternate, where Fhit $=47.14$ and Ftab $=$ 1, 47 which means that Fhit> Ftab. This is consistent with the results of this study that the learning model RQA applied researchers in class $X$ SMA 2 Kasimbar affect the understanding of the concept of the experimental class students, so understanding the concept of the experimental class students more than in understanding the concept of the control class.

It is also in accordance with that proposed by [10], about the advantages of constructivist models, namely:

- Thinking, in the process of fostering new knowledge, students' thinking to solve problems, find ideas and make decisions.

- Understand, therefore students are directly involved in developing new knowledge, they will better understand and can apply it in all situations.

- Remember, therefore students engage directly with active, they will remember longer all the concepts. Namely students through this approach of understanding their own build. Instead, they are more confident to face and solve problems in new situations.

- Social Skills, acquired social skills when interacting with peers and teachers in fostering new knowledge.

- Convenient, because they involved continuing, they understand, remember, confident and interact with healthy, then they will feel comfortable learning in fostering new knowledge.

Most students consider that biology is a difficult subject because it tends to be memorized. If this situation is allowed to continue for a long time, then, of course, will greatly influence students' attitudes toward biology. The attitude of the state's students like biology makes learning objectives will not be achieved. RQA learning model as one model of learning biology is a solution for students to increase student interest in the subject of biology and negative impression in biology learning can be eliminated.

\section{CONCLUSION}

Based on calculations and statistical analyzes were obtained as well as the discussion of the research that has been presented, it can be concluded that there is a learning model RQA influence the understanding of concepts and retention of class X SMA Negeri 2 Kasimbar in biology.

\section{REFERENCES}

[1]. BSNP. Panduan Penyusunan Kurikulum Tingkat SatuanPendidikan Jenjang Pendidikan Dasar Dan Menengah. Jakarta: Badan Standar Nasional Pendidikan, 2006.

[2]. Santyasa, I. W. Pembelajaran Berbasis Masalah dan Pembelajaran Kooperatif. Makalah pada Pelatihan Tentang Pembelajaran dan Asesmen Inovatif Bagi Guru-guru Sekolah Menengah, Nusa Penida, 2008.

[3]. Haerullah, A. Dan Fadlia, H.U. Pengaruh Penerapan Model Reading, Questioning and Anawering (RQA) terhadap Pengetahuan Metakognitif siswa Kelas XI IPA SMA Negeri 2 Ternate. Journal of Biologi Education FKIP UNKHAIR. 2, (1), 180-184. Tahun 2013.

[4]. Suparno, P. Filsafat Konstruktivisme dalam Pemdidikan. Yogyakarta: Kanisius, 2007.

[5]. Hasanuddin. "Implementasi Pembelajaran RQA Dipadu TPS Melalui Lesson Study Terhadap Hasil Belajar Mahasiswa". Journal of Biologi Education FKIP UNSYIAH Kuala Banda Aceh. 4, (1), 18-29. Tahun 2012.

[6]. Sugiyono. Metode Penelitian Kuantitatif kualitatif dan R\&D. Bandung: Alfabeta, 2011.

[7]. Riduwan. Metode dan Teknik Menyusun Tesis, Bandung: Alfabeta, 2004.

[8]. Ali, S. dan Khaeruddin. Evaluasi Pembelajaran.Makassar: Badan Penerbit UNM. 2012

[9]. Taha, Syamsumarlin. Model Pembelajaran Konstruktivisme. [Online]. Tersedia: http:manfaat model pembelajaran/syamsumarlin taha.htm [09 Februari 2017]. Tahun 2011.

[10]. Mursyidah, Ita. (2011). Manfaat Model Pembelajaran Konstruktivistik. [Online]. Tersedia: http:Downloads/ manfaatmodelpembelajaran.htm [09 Februari 2017]. 